\title{
THEORETICAL MODELS OF SOCIAL ENTERPRISES IN LATVIA
}

\author{
Lasma Licite \\ Latvia University of Life Sciences and Technologies, Latvia \\ lasma.licite@llu.lv
}

\begin{abstract}
Social entrepreneurship plays an increasingly important role in tackling socio-economic problems. It has gained recognition in Latvia among politicians, academicians and social entrepreneurs; consequently, the number of social enterprises increased in the country, yet there is a lack of research studies on social enterprise models and their classification. Accordingly, the research aim is to examine the theoretical models of social enterprises in Latvia. In the scientific literature, there is no strict classification of social enterprises, but based on different criteria, it is possible to distinguish several types or models. In Latvia, there are relatively few social enterprises; for this reason, it is quite difficult to categorise them. However, social enterprises are divided by sector, field of activity, target group, scale of activity and other criteria. The research stresses the following key social entrepreneurship models: the Selfinitiative Model, the Government Participation Model, the Municipal Participation Model and the Company-initiated Development Model. These models are based on two key criteria - support intensity and taking the initiative in establishing and developing a social enterprise.
\end{abstract}

Key words: social entrepreneurship, social enterprises, social enterprise models, classification of social enterprises.

\section{Introduction}

Over the last years, the activities in the field of social entrepreneurship take place in scientific research, government policies, education, and the commercial sector (Mair, Robinson, \& Hockerts, 2006; Nicholls, 2006; Perrini, 2006). It is an important tool to tackle social challenges and to respond to them when the market and the public sector do not. Social entrepreneurs create innovative initiatives and solutions to unsolved social problems, as a result they create benefit to different individuals and groups (Sekliuckiene \& Kisielius, 2015; Dees, 2007). Besides, social entrepreneurship is important in developing social innovations that are focused on meeting social needs of the society (Dobele, Grinberga-Zalite, \& Kelle, 2015).

Social entrepreneurship gains an increasing recognition in Latvia too, which is indicated by the fact that the Social Enterprise Law came into force on 1 April 2018. Social enterprises also have an opportunity to acquire grants under the Ministry of Welfare and ALTUM support programme in the range from EUR 5000 to 20000 for the establishment or development of a social enterprise, which is the first significant instrument of this kind aimed at promoting social enterprises in Latvia.

Given the urgency and the increasing role of social entrepreneurship, it has been researched by several scientists in Latvia as well. The first extensive research about foreign experiences with social entrepreneurship and its basic principles were studied in 'Latvia towards Social Entrepreneurship' (2012). Later the topicality of social entrepreneurship in the economic situation of Latvia was highlighted by I. Kalve (2012), V. Bikse, B. Rivza and I. Riemere (2014), J. Dehtjare and V. Riashchenko (2015), L. Dobele (2011, 2012a, 2012b, 2016a, 2016b), R. Lukjanska, M. Leszczyna-Rzucidlo and J. Kuznecova (2017), L. Paula and A. Grinfelde (2017). Social entrepreneurship in Latvia is analysed also within the context of municipalities - the role of local government in social entrepreneurship and support mechanisms which the local government can provide to social enterprises (Pūķis, 2012; Lukjanska, Kuznecova, \& Cirule, 2017; Lis et al., 2017). However, in various information sources in Latvia, the phrases "social enterprise" or "social entrepreneurship" appear mainly as descriptions of social enterprises and situation in social entrepreneurship of Latvia. Even though an extensive study by the European Commission on the social entrepreneurship ecosystem was carried out in 2015 (A map of social..., 2014), there is still a lack of scientific findings about social enterprise models and their classification.

The research aim is to examine the theoretical models of social enterprises in Latvia. To achieve the aim, the following specific research tasks were set: 1) to examine the kinds of social enterprises and the classification thereof; 2) to identify the theoretical models of social enterprises in Latvia.

\section{Materials and Methods}

The paper is built on the analysis and synthesis of scientific literature which allow to describe the models and classification of social enterprises. According to that, several research methods were applied: monographic, descriptive, analysis and synthesis, induction and deduction.

To identify the theoretical models of social enterprises in Latvia, expert interviews with the following social entrepreneurship representatives were carried out in Latvia:

1. Madara Ūlande - the director of Social Entrepreneurship Association of Latvia, which is a member organization for organizations, 
enterprises and individuals who want to promote social entrepreneurship in Latvia;

2. Vita Brakovska - the head of non-governmental organization 'ZINIS', innovation expert; conducts and organizes workshops about creativity, social entrepreneurship for different stakeholders;

3. Dace Indrika - a member of the Social Business Ambassador Network in Latvia.

4. Andris Bērziñš - the head of Samaritan Association of Latvia that provides various social, medical and educational services with the mission to improve the life quality for different risk groups in Latvia. One of social enterprises that participated in cofunding of Social Entrepreneurship Association of Latvia.

The selected experts represent diverse stakeholder groups in order to get comprehensive insight into the models of social enterprises in Latvia.

\section{Results and Discussion}

Theoretical framework of social enterprise models. A number of authors have sought to classify social enterprises, distinguishing the theoretical models of the enterprises (Alter, 2007; Grassl, 2012; Gawell, 2014; Wiguna, Ananda, \& Susilo, 2015). However, there is no strict classification of social enterprises, but based on their activities it is possible to separate several types or models.

D. Crossan et al. (2003) describe the types of social enterprises based on their legal form, working field and the sector they are operating in. As a result, they distinguish several social enterprise hybrid models.

A.B. Wiguna, C.F. Ananda and Susilo (2015) mention two types of social enterprises. They describe the model of social entrepreneurship which is a model of value creation process that focuses on the economic aspect (individual needs) at the beginning and after that on social aspect. This model mainly encourages economic independence that allows to transfer the economic surplus to society. Model of socio-entrepreneurship, on the other hand, is a model of value creation process during which the focus is on the social aspect (collective needs). This model mainly encourages collective initiation of value creation, therefore it not only makes an economic independence but also a growth cluster in society at the same time.

K. Alter (2007) elaborated typology that explores how institutions have combined a mix of social values and goals with commercial business practices, and how they have come up with ownership models, income and capitalization strategies, as well as unique management and service systems designed to maximize social value. K. Alter classified social enterprises based on their mission orientation (mission-centric, missionrelated and unrelated to mission), business / program integration (embedded social enterprises, integrated social enterprises, external social enterprises). In accordance with the social enterprise's financial and social objectives, mission, marketplace dynamics, client needs or capabilities, and legal environment the researcher has designed operational models of social enterprises. There are 10 fundamental models of social enterprises (Entrepreneur Support Model, Market Intermediary Model, Employment Model, Fee-for-Service Model, Low-Income Client as Market Model, Cooperative Model, Market Linkage Model, Service Subsidization Model, Organizational Support Model), two Combining Models (Complex Model, Mixed Model) and two Enhancing Models (Franchise Model, Private-Nonprofit Partnership Model) (Alter, 2007).

M. Gawell (2014) distinguishes four kinds of social enterprises:

1. social entrepreneurship as business with a social purpose,

2. social entrepreneurship and social enterprises based on non-profit principles,

3. social-economy-based entrepreneurship and workintegrating social enterprises,

4. social entrepreneurship as societal entrepreneurship.

One of the latest classifications is made by EMES Network. According to it four social enterprise organizational models are identified on the basis of three dimensions: the nature of the social mission, the type of economic model, and the governance structure.

1. Entrepreneurial non-profit organizations: developing any type of (related or unrelated) earned-income business in support of their social mission.

2. Social cooperatives: the social cooperative model aims to implement forms of democratic governance, i.e. equal voting power in the general assembly and limitation of capital shares' remuneration. However, it goes beyond most conventional cooperatives in that the social cooperative combines the pursuit of its members' interests with the pursuit of the interests of the whole community or of a specific target group.

3. Social businesses: considering social enterprise as a mission-driven business is the dominant view among business schools, consultancy firms, various foundations, which foster more broadly business methods as an efficient path to address social problems. For them, social enterprises are companies developing business activities for a primary social purpose or mission.

4. Public-sector social enterprises: social enterprises can emerge as 'public-sector spin-offs'. In the framework of community development policies targeting deprived urban areas, for instance, local 
public bodies may take the lead in setting up community enterprises seeking local development (Nyssens, s.a.).

These four models are characterized by specific trajectories driven by two distinct groups of institutional transformations (Defourny \& Nyssens, 2016). The first group corresponds to shifts from capital and mutual interest towards the general interest and results in organisations such as social cooperatives and social businesses. The second relates to marketization and it is observable in non-profit and public organisations. These two groups of institutional transformations leave long-lasting marks on social enterprise governance. Given the particular path dependency of social cooperatives and social businesses, a key governance challenge in the pursuit of the general interest is to avoid the profit motive dominating the social mission. Secondly, among public and nonprofit organisations, there is a movement towards marketization as a result of dramatic changes in the funding of goods and services of general interest. If social cooperatives and social businesses are used to operating in the market, public organisations and nonprofit organisations were hitherto traditionally relying on non-market income; they were fully subsidized by public authorities or mixing public financing and philanthropic resources. Overall, SEs can be seen as hybrid organisations shaped by institutional trajectories. Their double bottom line combines market and non-market resources; general interest and, in some cases, mutual or financial interests; and economic activity and social or societal goals.

Social enterprise models in Latvia. Social enterprises could be classified by taking into account different criteria: economic performance, social impact, field of activity, target groups, scale of activity etc. However, it has to be taken into account that there are relatively few social enterprises in Latvia; for this reason, it is quite difficult to categorise them.

Sectors. The social enterprises operate in various sectors including, but not limited to social services, production of goods, health services (including prevention), charity shops, environmental protection, cultural diversity \& heritage, education, work integration, consulting, information, and communications (Lis et al., 2017).

Field of activity. There is a strong trend to integrate socially sensitive groups of people in creating design objects. This might be due to the influence of one of the very first 'modern' social enterprises in Latvia, MAMMU, that worked with designers to create a prototype for scarves and afterwards young mothers from different regions participated in the production of this product (Lis et al., 2017). The development of design products could be explained by the fact that the Latvian market is small, and entrepreneurs seek to develop high value-added design products rather than focus on the market of consumer products. Social enterprises such as 'Blind Art', 'Ceribu sparni', 'DP Production' and many others also provide good examples of design products. Even though they are able to provide good quality products, many of these enterprises struggle with marketing, sales and access to global markets (Lis et al., 2017).

Target groups. A lot of social enterprises are so called work integration social enterprises because they work with socially sensitive groups of people: single mothers, disabled people (mental disabilities; physical disabilities; visually impaired people), elderly people, refugees, children and youth, parents and teachers, former inmates and their families. Also, there are social enterprises that are active in sustainable development, e.g. recycling old materials into clothes or art objects. But, often the two target activities - work integration and sustainable development - go together hand in hand (A map of social..., 2014).

Economic performance. There are no statistics available on the aggregate annual turnover of social enterprises, but it is likely not significant. The turnover of individual enterprises varies widely from a couple of thousand annually to a couple of million, depending on the size and the scope of the enterprise. It should be stressed that most social enterprises are relatively new, having been established only within the last 3 to 7 years, and usually do not employ more than five people (Lis et al., 2017).

Scale of activity. After examining various social enterprises in Latvia, one can conclude that their scale of operation is mainly local - within a region, a city, a municipality. Fewer enterprises operate at the national level and almost not a single one operates at the global level. In Latvia, it is important to promote social entrepreneurship in the context of global export ambitions, so that the social enterprises are competitive in the global market.

Social entrepreneurship expert V. Brakovska distinguishes three main types of social enterprises:

1. 'Profit generator' - economic activity makes no social impact, yet profits are allocated for this purpose.

2. 'Trade-off' - economic activity makes a social impact and a trade-off is made between the profit margin and the social impact.

3. 'Joint pace' - economic activity makes a social impact and generates profits.

If classifying social enterprises broadly, she distinguishes seven models of social enterprises in Latvia based on K. Alter's typology of social enterprises:

1. Employment and skills training. These enterprises employ socially excluded groups. The examples of such enterprises in Latvia are 'BlindArt' (employs 
the blind and persons with sight impairment) and 'Humusa komanda' (employs refugees).

2. Fee for service. Special shops (products are donated or bought at lower prices) have been established for the risk groups. An example in Latvia is the enterprise HOPP that produces threewheeled bicycles for seniors and persons with mobility impairment.

3. Market intermediary. A social enterprise is an intermediary that promotes the social risk group in the market, and profits are allocated for the expansion of the enterprise. An example in Latvia is the enterprise 'Lude' that produces cloth rugs from textile residue and seniors are engaged in this activity.

4. Market connector. A social enterprise helps the risk group to establish trade relations in new markets. An example in Latvia is the enterprise 'Projektu banka'. The concept of direct marketing also fits the principles of this model - organic produce is promoted in new markets.

5. Cooperative. The risk group is members of a cooperative who promote their products through the cooperative. An example in Latvia is the Latvian association of disabled women 'Aspazija'. Support instruments and initiative. Social enterprise models can be designed also based on such factors as taking the initiative (or the cooperation partner) and the intensity of support instruments:

1. the Self-initiative Model;

2. the Government Participation Model;

3. the Municipal Participation Model;

4. The Company-initiated Development Model.

A schematic depiction is shown in Figure 1.

To examine the models in detail, their nature and risks are specified.

Self-initiative Model. The foundation of a social enterprise is an individual-initiated activity, which does not involve significant support from a local or national government-owned or a conventional enterprise. The social entrepreneurs are involved in social enterprises because of their social mission and good will. In this model, social entrepreneurs identify themselves as social entrepreneurs, but do not apply to the status of a social enterprise, thus not receiving potential benefits.

The greatest risk in this model is the financial sustainability of social enterprises. Also, it is hard to ensure initial capital and profitable operation during the first three years of their existence.

Government Participation Model. This model involves various support instruments focused on social enterprises, of which the most important one is the grant support programme for social entrepreneurship provided by the Ministry of Welfare and ALTUM. At the beginning of 2018 , there was only one social enterprise in Latvia that had received a grant for its expansion - 'BlindArt'. The size of the grant was EUR 20 thousand, which would be used by the enterprise to integrate individuals with sight impairment into the labour market.

The biggest risk of this model is that a social enterprise can become dependent on grant funding and, after the grant is spent, cannot continue operating on its own.

MunicipalParticipation Model. Local governments can solve socio-economic problems in various ways. One of the opportunities is collaboration with social enterprises. The Social Enterprise Law provides an opportunity for local governments to engage in the activities of social enterprises in two ways - as coowners and as cooperation partners/supporters.

1. Local government as a co-owner of a social enterprise. The status of social enterprise may be acquired by a limited liability company, in which one or several public persons do not have

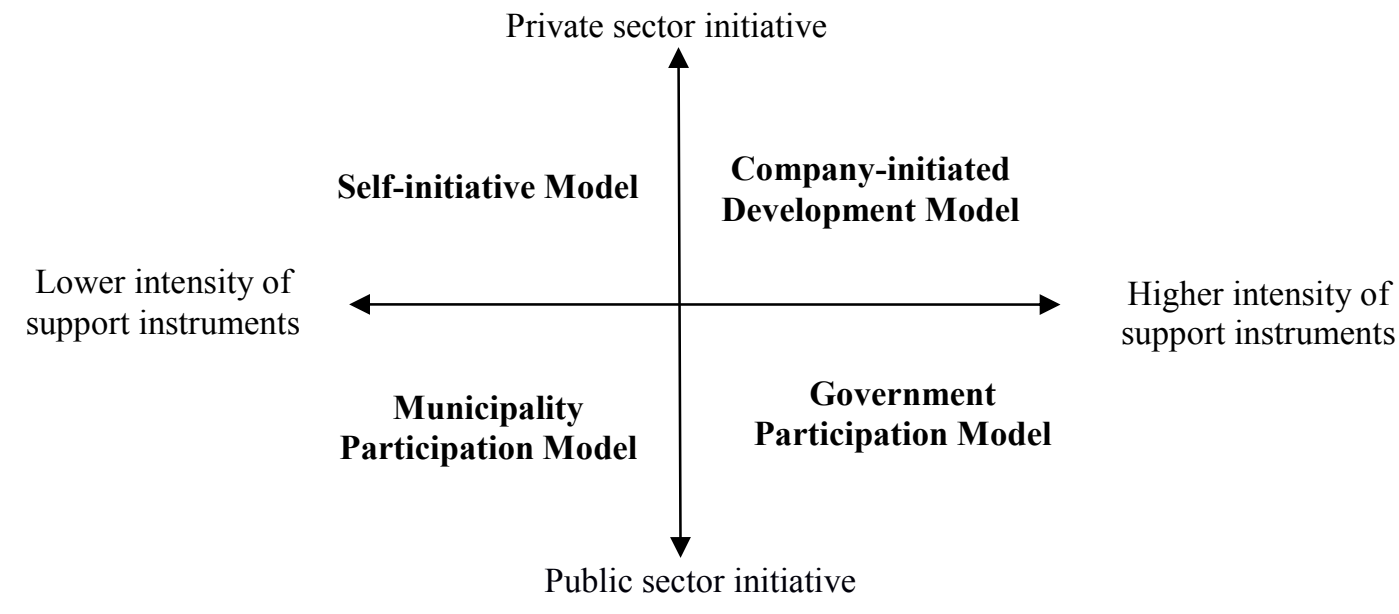

Source: author's construction.

Figure 1. Social enterprise models in Latvia based on support instruments \& initiative. 
a majority of votes if the goal set in the statute of the social enterprise is the employment of target audiences. However, this provision of the Social Enterprise Law will not be in force after 1 April 2021. This means that although a local government may establish social enterprises, it may be only a co-owner having no majority of votes, and only for labour integration social enterprises; besides, the local government has to 'exit' the social enterprise before 1 April 2021.

2. Local government as a cooperation partner/ supporter. Local governments, after the Social Enterprise Law becomes effective, may support social enterprises in various ways, including granting tax relief, free use of property, introducing other support instruments (e.g. special grant programmes). The Law does not oblige them to do it, yet it allows to do it, which is important in the case of local governments, so that they can legally establish their local social entrepreneurship support schemes.

In Latvia, successful patterns of cooperation between social enterprises and local governments can be mainly seen in the field of social services. One of the positive examples is observed in Sigulda where the local government cooperates with the social enterprise 'Ceribu sparni', as well as the Latvian Samaritan Association provides quality social services for municipalities. However, in general, cooperation depends on the duration of the partnership, the professional competence of local government officials and their general interest in the services or products provided by the social enterprise.

A significant problem is the fact that local governments do not see or do not estimate the real social effects resulting from the operation of a social enterprise; for this reason, the local authority might not wish to support it. Besides, it is often observed that a local government expects the social services to be provided by social enterprises free of charge or at a significant discount.

Company-initiated Development Model. The foundation of a social enterprise is initiated by companies or banks or they are trustful and stable cooperation partners for the social enterprise. The potential collaboration forms are described below.

1. Cooperation pattern of a conventional and a social enterprise may involve the delegation of certain functions of a conventional enterprise to a social enterprise. As a result of cooperation the products are sold to a conventional enterprise, thus reducing the risk of sales. This cooperation model is present in the operation of such social enterprise as HOPP that produces tricycles and aid transport for people with disabilities. The enterprise operates as a daughter enterprise under the 'wing' of a larger conventional enterprise. Similar experience has also been built up by the Web platform mammamuntetiem.lv connecting new families, and educating and informing about the most important topics regarding children health, safety and family life. Mammamuntetiem offers its services to large enterprises that have recognised them to be family experts in Latvia, thereby calling for the implementation of various social projects for family support in Latvia.

2. Bank loans and social investment to social enterprises. A practice of granting loans at a low interest rate or interest-free loans, which provides a social enterprise with current assets, has not yet emerged in Latvia. Nevertheless, such a practice could contribute to the development of social enterprises in the future, especially after 2022 when the grant support programme is over.

In this model, a social enterprise enjoys greater stability and security owing to a sales partner. However, one of the risks in this model is that banks might grant no loan to a social enterprise because they do not see it as a self-sustaining business model. Besides, investors very often think that social enterprises are less profitable comparing with conventional enterprises. These perceptions may be explained by the fact that investors have lack of knowledge about the social effect of social enterprises. Conventional enterprises, however, might perceive the cooperation pattern as a way of getting rid of unprofitable kinds of business, thereby contributing to their own benefit.

\section{Conclusions}

1. In the scientific literature, there is no strict classification of social enterprises, but based on different criteria it is possible to separate several types or models according to their legal form, working field, sector they are operating, the nature of the social mission, the type of economic model, and the governance structure.

2. In Latvia, there are relatively few social enterprises; for this reason, it is quite difficult to categorise them. However, social enterprises can be classified by sector, field of activity, target groups, scale of activity and other criteria.

3. The research distinguishes the following key social entrepreneurship models: the Self-initiative Model, the Government Participation Model, the Municipal Participation Model and the Companyinitiated Development Model. Social enterprise models are designed based on two factors affecting the development of social enterprises - taking the initiative (or the cooperation partner) and the intensity of support instruments.

4. The Self-initiative Model represents an individualinitiated activity, which does not involve significant 
support from a local or national governmentowned or a conventional enterprise. The other social enterprise models identified are based on support instruments from local governments and state-owned or conventional enterprises, thereby ensuring the sustainability and viability of social enterprises.

\section{References}

1. Alter, K. (2007). Social Enterprise Typology. Virtue Ventures LLC.

2. A map of social enterprises and their eco-systems in Europe (2015). European Commission.

3. Bikse, V., Rivza, B., \& Riemere, I. (2014). The Social Entrepreneur as a Promoter of Social Advancement. Procedia - Social and Behavioral Sciences, 185, 469-478. DOI: 10.1016/j.sbspro.2015.03.405.

4. Crossan, D., Bell, J., \& Ibbotson, P. (2003). Towards a Classification Framework for Social Enterprises. Retrieved March 10, 2018, from: https://www.aspc.unsw.edu.au/sites/www.aspc.unsw.edu.au/files/ uploads/aspc_historical_conferences/2005/paper9.pdf.

5. Dees, J.G. (2007). Taking social entrepreneurship seriously. Society, 44(3), 24-31. DOI: 10.1007/ BF02819936.

6. Defourny, J., \& Nyssens, S. (2016). Fundamentals for an international typology of social enterprise models. Retrieved March 10, 2018, from: https://www.iap-socent.be/sites/default/files/Typology\%20$\% 20$ Defourny\%20\%26\%20Nyssens_0.pdf.

7. Dehtjare, J., \& Riashchenko, V. (2015). Social entrepreneurship: issues and trends. Information Technologies, Management and Society, 8(1), 7-11.

8. Dobele, L. (2016a). A New Approach in Higher Education: Social Entrepreneurship Education. In Management, Enterprise and Benchmarking in the 21st Century III, 29-30 April 2016 (pp. 227-238). Budapest, Hungary: Obuda University.

9. Dobele, L. (2016b). The Legal Framework and Support Instruments for Social Entrepreneurship Development in Latvia. In The Innovative Content of Caritative Social Work, Vol. 4. (pp. 234-246). Rīga, Latvia: Latvia Christian Academy.

10. Dobele, L., Grinberga-Zalite, G., \& Kelle, L. (2015). Sustainable economic development: scenarios for promotion of social innovation in Latvia. Journal of Security and Sustainability Issues: International Entrepreneurial Perspectives and Innovative Outcomes, 5(2), 149-158.

11. Dobele, L. (2012a). Social Entrepreneurship Problems and Solutions: a Case Study of Latvia. West East Journal of Social Sciences, 1(1), 11-25.

12. Dobele, L. (2012b). Social Entrepreneurship Paradigm and its Assessment in Latvia. In Economic Science for Rural Development: Integrated and sustainable development, 26-27 April 2012 (pp. 55-63). Jelgava, Latvia: Latvia University of Agriculture.

13. Dobele, L. (2011). Influencing Factors of Social Entrepreneurship in Latvia. In Research for Rural Development' 2011, 18-20 May 2011 (pp. 101-107). Jelgava, Latvia: Latvia University of Agriculture.

14. Gawell, M. (2014). Soci (et al.), Entrepreneurship and Different Forms of Social Enterprise. In A. Lundstrom, C. Zhou, Y. von Friedrichs \& E. Sundin (Eds.), Social Entrepreneurship. Leveraging Economic, Political, and Cultural Dimensions (pp. 23-41). Springer International Publishing Switzerland.

15. Grassl, W. (2012). Business Models of Social Enterprise: A Design Approach to Hybridity. ACRN Journal of Entrepreneurship Perspectives, 1 (1), 37-60.

16. Kalve, I. (2012). Social entrepreneurship and information about it in the internet environment in Latvia. In 13th International Scientific Conference of the School of Business Administration Turiba, Sustainable Business under Changing Economic Conditions, 30 March 2012 (pp. 233-241). Riga, Latvia: School of Business Administration Turība.

17. Lešinska, A., Litvins, G., Pīpiḳe, R., Šimanska, I., Kupcis, O., \& Bušēvica, K. (2012). Latvija ceḷā uz sociālo uznēmējdarbību (Latvia towards Social Entrepreneurship). Retrieved March 10, 2018, from: http:// politika.lv/article_files/2264/original/SU_gala_9nov.pdf?1352702725. (in Latvian).

18. Lis, A., Wallberg, N., Nordstrom, T., Suvajevs, A., \& Ülande, M. (2017). Social enterprises and municipalities: cooperation, partnerships and synergies. Retrieved March 10, 2018, from: https://static1. squarespace.com/static/5103d40fe4b065d4a1c32d90/t/5a731e0c8165f596c6f26472/1517493777002/ SEandMunicipalities-EN_v3.pdf.

19. Lukjanska, R., Kuznecova, J., \& Cirule, I. (2017). The development of social entrepreneurship in Latvia: the role of municipalities. International Journal of Business and Globalisation, 18(3), 318-336. DOI: 10.1504/IJBG.2017.083206. 
20. Lukjanska, R., Leszczyna-Rzucidlo, M., \& Kuznecova, J. (2017). Support mechanisms for social entrepreneurship in the Baltic Sea Region. International Business and Global Economy, 36, $262-274$. DOI: 10.4467/23539496IB.17.018.7466.

21. Mair, J., Robinson, J., \& Hockerts, K. (2006). Social entrepreneurship. Hampshire: Palgrave Macmillan.

22. Nicholls, A. (2006). Social entrepreneurship: new models of sustainable social change. New York: OUP.

23. Nyssens, M. (s.a.) Towards an International Typology of Social Enterprise Models. Retrieved March 10, 2018, from: http://esela.eu/wp-content/uploads/2017/05/EMES-ARTICLE-MAY-2017.pdf?dm_i=1Y95.

24. Paula, L., \& Grinfelde, A. (2017). Social economy in Latvia: The case of charity shops. In Economic Science for Rural Development, No 44, 27-28 April 2017 (pp. 136-141). Jelgava, Latvia: Latvia University of Agriculture.

25. Perrini, F. (2006). The new social entrepreneurship: what awaits social entrepreneurial ventures? Cheltenham: Edward Elgar.

26. Pūķis, M. (2012). Sociālās uzñēmējdarbības attīstības iespējas Latvijā (Social Entrepreneurship Development Possibilities in Latvia) Retrieved March 10, 2018, from: http://www.biznesa-attistiba.lv/ userfiles/file/Petijums_3.pdf. (in Latvian).

27. Sekliuckienea, J., \& Kisielius, E. (2015). Development of social entrepreneurship initiatives: a theoretical framework. Procedia - Social and Behavioral Sciences, 213, 1015-1019. DOI: 10.1016/j. sbspro.2015.11.519.

28. Wiguna, A.B., Ananda, C.F., \& Susilo (2015). Model of Social Entrepreneurship and Socioentrepreneurship: A Replica of Reality. Procedia - Social and Behavioral Sciences, 211, 27-33. DOI: 10.1016/j.sbspro.2015.1.005. 